\title{
Epilepsy and Pregnancy: A Retrospective Analysis of 101 Pregnancies
}

\section{Epilepsi ve Gebelik: 101 Gebeliğin Geriye Dönük Analizi}

\author{
- Aslı Ece ÇíLLiLER, ๑ Hayat GÜVEN, • Selim Selçuk çOMOĞLU
}

Department of Neurology, Dışkapı Yıldırım Beyazıt Training and Research Hospital, Ankara, Turkey

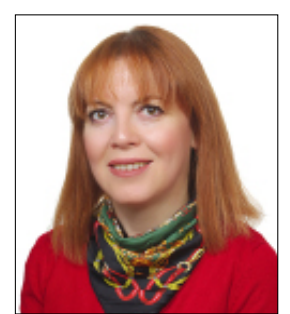

Dr. Aslı Ece ÇiLLILER

\section{Summary}

Objectives: Maintaining a balance between controlling epileptic seizures and potential teratogenic effects of anti-epileptic drugs (AEDs) is fundamental in epileptic pregnancies. We aimed to present demographic and clinical data of pregnant women with epilepsy, and determine the potential complications that could occur with the use of AEDs.

Methods: A total of 101 pregnancies of 55 epileptic women were retrospectively evaluated. Demographic characteristics, duration of epilepsy, seizure frequency, type and doses of AEDs, delivery mode, birth weight of infants, malformations, abortions, early deliveries, and still-births were registered.

Results: Out of 190 patients 55 (28.9\%) had experienced pregnancy, and a total number of pregnancies was 101. Mean age of patients was $30.7 \pm 9.7$ years and mean duration of epilepsy was $14.5 \pm 10.8$ years. 50 (61.7\%) had experienced at least one seizure during pregnancy, while no epileptic seizures were observed in 31 (38.3\%). 19.8\% resulted in spontaneous abortion, $72.3 \%$ with term live birth, $4.9 \%$ in preterm delivery, $2 \%$ in still-birth, and $1 \%$ in premature still-birth. Mean birth weight of infants whose mothers had no AED treatment, those under monotherapy, and those under polytherapy during pregnancy was $3065.4 \mathrm{~g}, 2941.3 \mathrm{~g}$, and $2696.6 \mathrm{~g}$, respectively. Congenital malformations, namely dextrocardia, hypospadias, and horseshoe kidney were observed in newborns.

Conclusion: Epileptic pregnancies frequently result with the delivery of a healthy infant. Planning of antiepileptic therapy in the pre-conceptional period, using the appropriate AED for woman's seizure disorder as monotherapy in the lowest effective dose throughout pregnancy is important.

Keywords: Antiepileptic drugs; epilepsy; pregnancy; seizure.

\section{Özet}

Amaç: Epileptik gebeliklerde nöbetlerin kontrolü ile anti epileptik ilaçların (AEi) olası teratojen etkileri arasında dengenin sağlanması esastır. Bu çalışmada epilepsi tanısı ile izlenen gebelere ait demografik ve klinik verilerin sunulması, AEl kullanımı ile oluşabilecek potansiyel komplikasyonların belirlenmesi amaçlandı.

Gereç ve Yöntem: Elli beş epileptik gebe kadına ait 101 gebelik verisi geriye dönük olarak incelendi. Hastaların demografik özellikleri, epilepsi süreleri, nöbet sıklıkları, kullandıkları AEl'ler ve dozları, doğum yöntemleri, infantların doğum ağırlıkları, fetal malformasyonlar, abortuslar, erken doğum ve ölü doğumlar değerlendirildi.

Bulgular: Yüz doksan hastanın 55'inin (\%28.9) gebelik yaşamış olduğu ve toplam gebelik sayısının 101 olduğu tespit edildi. Hastaların yaş ortalaması 30.7 \pm 9.7 , ortalama epilepsi süresi $14.5 \pm 10.8$ yıl idi. Yüz bir gebeliğin 50'sinde (\%61.7) gebelik süresince en az bir kez nöbet geçirildiği saptanırken, 31 gebelikte ise (\%38.3) nöbet gözlenmemişti. Gebeliklerin \%19.8'i spontan abortus, \%72.3'ü miadında canlı doğum, \%4.9'u erken doğum, \%2'si ölü doğum ve \%1'i ise prematüre ölü doğum olarak sonuçlanmıştı. Gebeliğinde AEi kullanmayan, monoterapi kullanan ve politerapi kullanan hastaların yenidoğanlarının ortalama doğum ağırlıkları sırasıyla 3065.4 gr, 2941.3 gr, 2696.6 gr olarak saptandı.Yenidoğanlarda görülen doğumsal malformasyonlar; dekstrokardi, hipospadias ve at nalı böbrek idi.

Sonuç: Epileptik gebelikler sıklıkla sağlıklı bebek doğumu ile sonuçlanmaktadır. Antiepileptik tedavinin prekonsepsiyonel dönemde planlanması, hastaların politerapiden kaçınılarak, nöbet tipine uygun, en düşük doz AEl ile takip edilmesi bu hedefe ulaşılmasında önem taşımaktadır. Anahtar sözcükler: antiepileptik ilaçlar; epilepsi; gebelik; nöbet.

Submitted (Geliş): 05.01.2018 


\section{Introduction}

Epilepsy is one of the most common neurological disorders, affecting up to $2 \%$ of the population worldwide and it is the second most frequently encountered neurological disorder after migraine among females during pregnancy. ${ }^{[1,2]}$ Pregnancy of epileptic patients constitutes $0.3-0.5 \%$ of all pregnancies. ${ }^{[3]} \mathrm{A}$ balance is tried to be maintained between maternal and fetal risks of uncontrolled seizures and potential teratogenic effects of anti-epileptic medications in the management of epilepsy during pregnancy. ${ }^{[3]} A$ vast majority of women with epilepsy is able to deliver healthy infants. On the other hand, major or minor congenital malformations are 2-5 times more prevalent in children of epileptic women in comparison with the general population. ${ }^{[4,5]}$ Most frequent congenital malformations are cleft lip-palate, cardiac abnormalities, neural tube defects, skeletal and urogenital abnormalities, dysmorphic characteristics, behavioral disorders, and low IQ. ${ }^{[2,4]}$ Increased risks of abortion, stillbirth, premature delivery, intra-uterine developmental delay, and mental and psychomotor retardation were reported in pregnant patients with epilepsy. ${ }^{[6,7]}$

The most important aim in pregnant, epileptic patients are controlling epileptic seizures with the lowest effective drug dose. Planning of anti-epileptic therapy in the pre-conceptional period is important in achieving this goal. Pregnancies resulting in healthy deliveries similar to the general population are possible by avoiding polytherapy, following up on the lowest effective dose of appropriate anti-epileptic drugs (AED) for the seizure type and folate replacement.

Evaluation of pregnancy outcomes and determining potential complications of AED use in patients followed up with a diagnosis of epilepsy by presenting clinical data on their pregnancy periods were aimed in this study.

\section{Materials and Methods}

A total of 55 patients'101 pregnancies among 190 female patients followed up by the epilepsy outpatient clinics were included in this study. Patients with systemic or obstetric comorbidities that could affect the process of pregnancy were excluded.

Patient records were examined, and demographic characteristics including age, gravity, and parity, also the duration of epilepsy, frequency of epileptic seizures before and dur- ing pregnancy, medication use during pregnancy, AEDs, and their doses that were used during pregnancy were recorded. Increase, decrease, or absence of a change in the frequency of seizures was determined by comparing the total number of seizures during pregnancy and the number of epileptic seizures during the past year before pregnancy. The trimesters that patients had experienced seizures were recorded. Mode of delivery (normal spontaneous vaginal delivery [NSVD] and cesarean section [C/S]), birth weights of infants, fetal malformations, abortions, preterm deliveries, and stillbirths were analyzed. Deliveries before the $37^{\text {th }}$ gestational week were considered as prematurity.

Informed consents of patients included in this study were obtained, and the study was conducted in accordance with the World Medical Association Helsinki Declaration.

\section{Statistical analysis}

This study was conducted on a total of 101 pregnancies. The data were completed by transferring to IBM SPSS Statistics 23 software. Descriptive statistics were evaluated through the numbers, percentages, means, and standard deviations. Presence or absence of an association between categorical variables was assessed with the Chi-square test, and presence or absence of a difference between independent groups was assessed with one-way analysis of variance test. The level of statistical significance was accepted as $\mathrm{p}<0.05$.

\section{Results}

Data on 101 pregnancies of 55 epileptic patients were evaluated in this study. The mean age of patients was 30.7 \pm 9.7 years, and the mean duration of epilepsy was $14.5 \pm 10.8$ years. In $40.7 \%$ of the pregnancies, there was no drug during pregnancy, while $51.9 \%$ was on monotherapy and $7.4 \%$ on polytherapy. $50(61.7 \%)$ of the 81 pregnancies experienced at least one epileptic seizure during pregnancy, while no seizures were observed in 31 (38.3\%). There was an increase in the frequency of seizures in $25.9 \%$ of pregnancies, decrease in $30.9 \%$ and no change in seizure frequency in $43.2 \%$. In $4(8 \%)$ of the pregnancies seizures were in the $1 \mathrm{st}$ trimester, in 12 (24\%) in the 2nd trimester, 7 (14\%) in the 3rd trimester, and 27 (54\%) seizures were observed in all three trimesters (spontaneous abortions were not included as they could not complete the gestational period) (Table 1).

The AEDs and their doses that were used during pregnancy are shown in Table 2. 
Table 1. Demographic and clinical characteristics of epileptic pregnant patients

\begin{tabular}{lccc}
\hline & $\mathrm{n}$ & $\%$ & Mean \pm SD \\
\hline Age (years) & & & $30.7 \pm 9.7$ \\
Number of pregnancies & & & $1.8 \pm 1.2$ \\
Duration of epilepsy & & & $14.5 \pm 10.8$ \\
Seizures during pregnancy & & & \\
$\quad$ Seizures & 50 & 61.7 & \\
$\quad$ No seizures & 31 & 38.3 & \\
Frequency of epileptic & & & \\
seizures in pregnancy & & & \\
$\quad$ Increase & 21 & 25.9 & \\
$\quad$ Decrease & 25 & 30.9 & \\
$\quad$ No change & 35 & 43.2 & \\
Seizure time* & & & \\
$1^{\text {st }}$ trimester & 4 & 8 & \\
$2^{\text {nd }}$ trimester & 12 & 24 & \\
$3^{\text {rd }}$ trimester & 7 & 14 \\
$1^{\text {st }}$ 2 $^{\text {nd }}$, and $3^{\text {rd }}$ trimesters & 27 & 54 \\
Type of AEDs & & \\
No treatment & 33 & 40.7 \\
Monotherapy & 42 & 51.9 \\
Polytherapy & 6 & 7.4 \\
\hline
\end{tabular}

AED: Antiepileptic drug; SD: Standard deviation. *Spontaneous abortions were not included.

Out of a total of 101 pregnancies, $19.8 \%$ have resulted in spontaneous abortions, $72.2 \%$ in live birth at term, $4.9 \%$ in premature delivery, $1.2 \%$ in stillbirth, and $0.9 \%$ in premature stillbirth. $49.4 \%$ of pregnancies resulted in NSVD, while $50.6 \%$ were $\mathrm{C} / \mathrm{S}$ (Table 3 ).

The mean birth weight of newborns was $2973.76 \pm 659.59 \mathrm{~g}$. The mean birth weight of infants of the pregnant patients who have not taken AEDs during pregnancy was $3065.4 \mathrm{~g}$, mean birth weight of infants of whose mothers were on monotherapy was $2941.3 \mathrm{~g}$, and mean birth weight of infants whose mothers were on polytherapy was $2696.6 \mathrm{~g}$.

No statistically significant differences were detected between patients who have taken and who have not taken AEDs in terms of birth weights of newborns, spontaneous abortions, stillbirths, and delivery at term or premature deliveries $(p>0.05$ ) (Table 4).

We found no relationship between the type of epileptic seizures, AED use and the seizure frequency changes during pregnancy $(p>0.05)$ (Table 5).
Table 2. Anti-epileptic drugs that have been used during pregnancy and their doses

\begin{tabular}{lccc}
\hline Antiepileptic drugs & $\mathrm{n}$ & $\%$ & $\begin{array}{c}\text { Mean dose } \\
\text { (mg/day) }\end{array}$ \\
\hline Lamotrigine & 15 & 31.2 & 120 \\
Carbamazepine & 14 & 29.1 & 500 \\
Valproic acid & 7 & 14.5 & 821.4 \\
Levetiracetam & 2 & 4.2 & 750 \\
Phenobarbital & 1 & 2.1 & 100 \\
Phenytoin & 2 & 4.2 & 200 \\
Topiramate & 1 & 2.1 & 100 \\
Carbamazepine+Levetiracetam & 1 & 2.1 & $400 / 500$ \\
Carbamazepine+Lamotrigine & 4 & 8.4 & $775 / 131.2$ \\
Lamotrigine+Oxcarbazepine & 1 & 2.1 & $150 / 1800$
\end{tabular}

The data are presented as $\mathrm{n}(\%)$. Spontaneous abortions were not included.

Table 3. Characteristics of pregnancy outcomes

\begin{tabular}{lcc}
\hline & $\mathrm{n}$ & $\%$ \\
\hline Spontaneous abortion & 20 & 19.8 \\
Live birth at term & 73 & 72.3 \\
Premature delivery & 5 & 4.9 \\
Stillbirths & 2 & 2 \\
Premature stillbirths & 1 & 1 \\
Type of delivery & & \\
$\quad$ NSVD & 39 & 48.8 \\
$\quad$ C/S & 41 & 51.2 \\
\hline
\end{tabular}

The data are presented as $\mathrm{n}(\%)$. NSVD: Normal spontaneous vaginal delivery, $\mathrm{C} / \mathrm{S}$ : Cesarean section.

Epileptic seizures were observed in two patients (3.6\%) during delivery and one patient had to undergo a hysterectomy due to postpartum uterine atony.

Dextrocardia was found in 1 infant, hypospadias in 1 infant and horseshoe kidney in 1 infant in this study. The type and doses of AEDs used by the mothers of infants having these malformations are presented in Table 6 . Two of the infants (2.4\%) were reported to have a diagnosis of epilepsy in the following period.

\section{Discussion}

Most women with epilepsy today can conceive and bear normal, healthy children. Pregnancies were reported to resolve uneventfully in $>90 \%$ of epileptic women. ${ }^{[6-10]}$ On the other hand, it is also known that abortions, fetal loss, congenital malformations, and psychomotor devel- 
Table 4. Association between birth weights, stillbirths, spontaneous abortions, and prematurity rates of newborns according to the AED use of epileptic pregnancies

\begin{tabular}{lcccc}
\hline Pregnancy outcomes & Monotherapy & Polytherapy & No treatment & $\mathrm{p}$ \\
\hline Birth weight, Mean \pm SD & $2941.3 \pm 661.05$ & $2696.6 \pm 1254.98$ & $3065.45 \pm 507.19$ & 0.412 \\
Stillbirths, $\mathrm{n}(\%)$ & $1(33.3)$ & $1(33.3)$ & $1(33.3)$ & 0.430 \\
Spontaneous abortion, $\mathrm{n}(\%)$ & $6(30)$ & $3(15)$ & $11(55)$ & 0.183 \\
Delivery at term, $\mathrm{n}(\%)$ & & & & \\
$\quad$ Term delivery & $38(50.7)$ & $5(6.7)$ & $1(16.7)$ & 0.426 \\
$\quad$ Premature delivery & $4(66.7)$ & $1(16.7)$ & $16.7)$ & \\
\hline
\end{tabular}

AED: Anti-epileptic drugs; SD: Standard deviation.

Table 5. Association between seizure type, drug use, and seizure frequency change in epileptic pregnancies (spontaneous abortions were not included)

\begin{tabular}{lcccc}
\hline $\begin{array}{l}\text { Type of seizures and AED } \\
\text { regimens }\end{array}$ & $\begin{array}{c}\text { Increase in seizure } \\
\text { frequency }\end{array}$ & $\begin{array}{c}\text { Decrease in seizure } \\
\text { frequency }\end{array}$ & $\begin{array}{c}\text { No change in seizure } \\
\text { frequency }\end{array}$ & $\mathrm{p}$ \\
\hline $\begin{array}{l}\text { Type of seizures, } \mathrm{n}(\%) \\
\quad \text { Partial }\end{array}$ & $1(11.1)$ & $4(44.4)$ & $4(44.4)$ & 0.220 \\
$\quad$ Generalized & $10(20.4)$ & $16(32.7)$ & $23(46.9)$ & $8(34.8)$ \\
$\quad \begin{array}{l}\text { Partial+sec. gen. } \\
\text { Anti-epileptic drugs use, } \mathrm{n}(\%)\end{array}$ & $10(43.5)$ & $5(21.7)$ & $19(45.2)$ & 0.820 \\
$\quad$ Monotherapy & $12(28.6)$ & $11(26.2)$ & $2(33.3)$ & \\
$\quad$ Polytherapy & $1(16.7)$ & $3(50)$ & $14(42.4)$ & \\
No treatment & $8(24.2)$ & $11(33.3)$ & & \\
\hline
\end{tabular}

Table 6. Types of congenital malformations by AED and drug dose

\begin{tabular}{lcc}
\hline Malformations & AED used & $\begin{array}{c}\text { AED dose } \\
\text { (mg/day) }\end{array}$ \\
\hline Dextrocardia & Carbamazepine & 1000 \\
Hypospadias & Carbamazepine & 400 \\
Horseshoe kidney & Lamotrigine/ & $150 / 1800$ \\
& Oxcarbazepine & \\
\hline
\end{tabular}

AED: Anti-epileptic drugs.

opmental delay are more prevalent in epileptic pregnant patients in comparison with the general population. ${ }^{[2,6,8]}$ Malformation rates are between $2 \%$ and $3 \%$ in the general population, while in some studies this rate is reported as $1.25-11.5 \%$ in infants exposed to AEDs. ${ }^{[11]} \mathrm{A}$ general consensus is that the incidence of malformations in epileptic women is $2-3$ times higher. ${ }^{[3,12]}$ Multifactorial interactions including most prominently AED use, increase in the frequency of epileptic seizures, and genetic characteristics were supposed to be responsible for this increased malformation risk.
In the present study, at least one epileptic seizure was observed in 50 pregnancies $(61.7 \%)$ during pregnancy, whereas no seizures were seen in 31 (38.3\%). We observed an increase in seizure frequency in $25.9 \%$, a decrease in $30.9 \%$, and no changes in $43.2 \%$ of pregnancies. Epileptic seizures were observed in the $1^{\text {st }}$ trimester in $8 \%$, in the $2^{\text {nd }}$ trimester in $24 \%$, and in the $3^{\text {rd }}$ trimester in $14 \%$, while seizures were observed in all trimesters in $54 \%$ of pregnancies. Status epilepticus did not develop in our patients during pregnancy. The frequency of seizures may increase, decrease or may not change during pregnancy. The general consensus is toward no changes in the frequency of epileptic seizures in the majority of patients. The best marker that may reflect the frequency of seizure during pregnancy is the frequency of seizures during the past year before pregnancy. ${ }^{[13]}$ In the EURAP study based on 1736 pregnancies, concluded that $58.3 \%$ of the patients were seizure-free, $15.9 \%$ showed a decrease in the seizures, and convulsive seizures were reported in $17.3 \%$. Status epilepticus was observed in $1.8 \%$ of the patients. ${ }^{[14]}$ In another study, seizures were observed in $81 \%$ of 333 epileptic pregnant patients. ${ }^{[15]}$ In some studies, the increase in the seizure frequency is reported to be more 
prominent in the $1^{\text {st }}$ and $3^{\text {rd }}$ trimesters, ${ }^{[16,17]}$ others have reported a decrease in seizure frequency in the $1^{\text {st }}$ trimester. ${ }^{[3,18]}$ We found that seizures are least frequent in the $1^{\text {st }}$ trimester in the present study. Location-related epilepsies, the duration and severity of illness, frequent seizures before pregnancy, stress, sleep deprivation, fatigue, and increased ratio of estrogen/progesterone were found to be associated with an increase in seizures. ${ }^{[3]}$ As a result of physiologic changes during pregnancy like decreased binding to proteins, defective gastrointestinal absorption, and increase in the volume of distribution causes a decrease in the plasma concentrations of many AEDs resulting an increase in seizure frequency. Furthermore, discontinuing the use of AEDs due to concerns on their negative effects on the fetus may cause an increase in seizures. ${ }^{[2,19]}$

Rates of spontaneous abortion, premature delivery, stillbirth, and premature still-birth were $19.8 \%, 4.9 \%, 2 \%$, and $1 \%$, respectively, in the present study. Spontaneous abortions occur in $15-40 \%$ of non-epileptic pregnancies. ${ }^{[20]}$ An increase of $13 \%$ was reported in the risk of spontaneous abortions in pregnant women receiving AEDs. ${ }^{[21]}$ Data showing more frequent pre-term delivery in epileptic pregnant patients are conflicting. Prematurity was reported between $5.36 \%$ and $33.3 \%$ in epileptic pregnant patients. ${ }^{[2,22]}$ An increase in the risk of stillbirth was shown in epileptic women using AEDs, but a statistically significant difference could not be found. ${ }^{[21]}$ Stillbirth was reported in $2.4 \%$ of patients in another study. ${ }^{[15]}$ Statistically significant differences were not found in the present study among pregnancies with no AED treatment and those on monotherapy or polytherapy in terms of spontaneous abortions, premature delivery, and stillbirths.

Among our sample, $49.4 \%$ were found to result in normal vaginal delivery, and $50.6 \%$ were found to result in $\mathrm{C} / \mathrm{S}$. Findings of studies on the rate of $C / S$ in epileptic pregnant patients are variable. ${ }^{[23,24]}$ Rate of normal delivery was $14.76 \%$ and $C / S$ was $79.20 \%$ in one study, ${ }^{[1]}$ while another study reports a rate of delivery with $\mathrm{C} / \mathrm{S}$ of $18 \% .{ }^{[22]} \mathrm{A}$ diagnosis of epilepsy is not considered as an indication for $\mathrm{C} / \mathrm{S}$ per se, except experiencing a seizure during delivery. ${ }^{[25]}$ In EURAP study, seizure during delivery was seen in $2.6 \%$ of the patients treated with lamotrigine and carbamazepine, while seizure was seen in $1.9 \%$ of those on phenobarbital and $1.4 \%$ of those on valproic acid. ${ }^{[26]}$ In this study, seizures during delivery were observed in 2 (2.4\%) of the untreated pregnancies. The risk of delivery complications is increased in epileptic women, but seizures do not explain this increased risk per se. ${ }^{[25]}$ Some studies have suggested pre-eclampsia, induction of labor, C/S, and instrumental deliveries such as forceps or vacuum use is more frequent in women with epilepsy. Furthermore, blood lost during delivery is higher amongst epileptic women, and ablatio placentae, Vitamin K deficiency, and hypotonic uterus have been suggested as important factors for vaginal bleeding.

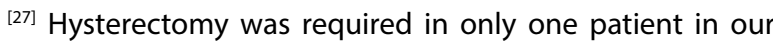
study, due to postpartum uterine atony.

In the present study, in $40.7 \%$ of pregnancies, no AED treatment was used during pregnancy, while $51.9 \%$ had monotherapy and 7.4\% had polytherapy. In only 12 (36.3\%) of the pregnancies with no AED, the treatment was stopped by the doctor because the disease was recovered. The remainders were found to have terminated the AEDs by themselves for the reason of pregnancy. The most frequently used drugs in this study were lamotrigine, carbamazepine, and valproic acid in the third place. Use of monotherapy during pregnancy cause less birth defects in comparison with polytherapy. Increasing the dose of a single drug is considered to be more appropriate than a switch to polytherapy by addition of a new AED, in terms of avoiding fetal complications. ${ }^{[2]}$ Most of the data on the treatment of epilepsy during pregnancy are on phenobarbital, phenytoin, carbamazepine, and valproic acid. The most teratogenic drug among AEDs is valproic acid. It is also the only AED that dose-related teratogenicity was shown. Its teratogenic effect is more prominent in doses over $800-1000$ mg. ${ }^{[28,29]}$ In UK epilepsy group study, the mean rate of malformation with valproic acid 600-1000 mg/day monotherapy was $6.1 \%$, while it was shown to increase to $9.1 \%$ when the dose was increased over $1000 \mathrm{mg} /$ day. The rate of malformation with carbamazepine was $2.2 \%$ and $3.2 \%$ with lamotrigine.

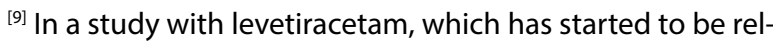
atively frequently used during pregnancy in recent years, the rate of major malformations was $0.66 \%$ in 304 epileptic pregnant patients with levetiracetam monotherapy, which increased to $5.2 \%$ when levetiracetam was used in combination with another AED. ${ }^{[30]}$ Risk of malformation increases considerably, especially when lamotrigine is combined with valproic acid. Major structural birth defects were shown in $1.8 \%$ of patients on lamotrigine monotherapy, while this rate increased to $4.3 \%$ with lamotrigine and combination with a non-valproic acid AED, and to $10 \%$ with lamotrigine and valproic acid. ${ }^{[9]}$ Malformations were detected in 3 (3.7\%) 
infants in this study group. Dextrocardia was found in the infant of a patient who had used carbamazepine $1000 \mathrm{mg} /$ day during pregnancy, hypospadias in an infant of a patient who had used carbamazepine $400 \mathrm{mg} /$ day, and horseshoe kidney in another infant whose mother had taken a combination of lamotrigine $150 \mathrm{mg} /$ day and oxcarbamazepine $1800 \mathrm{mg} /$ day. One of these three infants died in the $11^{\text {th }}$ months after delivery, due to dextrocardia. The risk of developing epilepsy in infants of patients who had cryptogenic epilepsy was reported to be $3 \%$. This rate increases to $9-12 \%$ in idiopathic generalized epilepsy. ${ }^{[28]}$ Another two of the infants in our study group (2.4\%) were reported to have a diagnosis of epilepsy in the following period.

More frequent low birth weight and short head circumference measurements, and negative effects on growth rate and cognitive development were reported in infants of mothers receiving AEDs. ${ }^{[3]]}$ Birth weights of newborns of epileptic patients were reported to be $208 \mathrm{~g}$ lower than the control group. ${ }^{[32]}$ In another study, mean birth weights of newborn infants of epileptic patients were shown to be lower than the controls, but the difference was not statistically significant. ${ }^{[33]}$ AED polytherapy has been suggested as a risk factor for low birth weight in comparison to monotherapy. ${ }^{[34]}$ In our study, the mean birth weights of infants whose mothers had no AED treatment during pregnancy were $3065.4 \mathrm{~g}$, while it was $2941.3 \mathrm{~g}$ whose mothers were on monotherapy and $2696.6 \mathrm{~g}$ whose mothers were on polytherapy. While these differences were not statistically significant, they have supported the opinion that polytherapy is a risk factor for low birth weight.

\section{Conclusion}

Results of our study show that epileptic pregnant patients possess a high probability of delivering healthy infants, while spontaneous abortions may be more frequent than expected, and AED use as polytherapy may be more frequently associated with low birth weights.

\section{Ethics Committee Approval}

This study was approved by the Dışkapı Yıldırım Beyazıt Training and Research Hospital Clinical Research Ethics Committee (approval number 31/24; June 27, 2016).

\section{Peer-review}

Externally peer-reviewed.

\section{Conflict of interest}

The authors declare that they have no conflict of interest.

\section{Authorship Contributions}

Concept: A.E.Ç., H.G.; Design: A.E.Ç., H.G.; Supervision: H.G.; Materials: A.E.Ç.; Data collection \&/or processing: A.E.Ç.; Analysis and/or interpretation: A.E.Ç.; Literature search: A.E.Ç., H.G.; Writing: A.E.Ç.; Critical review: S.S.Ç.

\section{References}

1. Centers for Disease Control and Prevention. Prevalence of self-reported epilepsy--United States, 1986-1990. JAMA 1994;272(24):1893. [CrossRef]

2. Ozdemir O, Sari ME, Kurt A, Sakar VS, Atalay CR. Pregnancy outcome of 149 pregnancies in women with epilepsy: Experience from a tertiary care hospital. Interv Med Appl Sci 2015;7(3):10813. [CrossRef]

3. Battino $D$, Tomson T. Management of epilepsy during pregnancy. Drugs 2007;67(18):2727-46. [CrossRef]

4. Güveli B, Gürses C, Ataklı D, Bebek N, Dörtcan N, Baykan B, et al. Are there any EEG changes in children whose mothers with epilepsy had used antiepileptic drug during pregnancy? J Neurol Sci Turk 2012;29(2):192-200.

5. Oguni M, Osawa M. Epilepsy and pregnancy. Epilepsia 2004;45(8):37-41. [CrossRef]

6. Morrell MJ. Reproductive and metabolic disorders in women with epilepsy. Epilepsia 2003;44(4):11-20. [CrossRef]

7. Madazlı R, Öncül M, Albayrak M, Uludağ S, Eşkazan E, Ocak V. Gebelik ve epilepsi: 44 olgunu değerlendirilmesi. Cerrahpaşa J Med 2004;35:126-30.

8. Yerby MS, Kaplan P, Tran T. Risks and management of pregnancy in women with epilepsy. Cleve Clin J Med 2004;71(2):S25-37.

9. Morrow J, Russell A, Guthrie E, Parsons L, Robertson I, Waddell $\mathrm{R}$, et al. Malformation risks of antiepileptic drugs in pregnancy: A prospective study from the UK epilepsy and pregnancy register. J Neurol Neurosurg Psychiatry 2006;77(2):193-8.

10. Lavi-Blau T, Ekstein D, Neufeld MY, Eyal S. Use of antiepileptic drugs during pregnancy and lactation: Type of information provided by searching google. Epilepsy Behav 2016;55:113-9.

11. Yerby MS. Clinical care of pregnant women with epilepsy: Neural tube defects and folic acid supplementation. Epilepsia 2003;44(3):33-40. [CrossRef]

12. Tomson T, Perucca E, Battino D. Navigating toward fetal and maternal health: The challenge of treating epilepsy in pregnancy. Epilepsia 2004;45(10):1171-5. [CrossRef]

13. Patel SI, Pennell PB. Management of epilepsy during pregnancy: An update. Ther Adv Neurol Disord 2016;9(2):118-29.

14. EURAP Study Group. Seizure control and treatment in pregnancy: Observations from the EURAP epilepsy pregnancy registry. Neurology 2006;66(3):354-60. [CrossRef]

15. Meador KJ, Baker GA, Finnell RH, Kalayjian LA, Liporace JD, Loring DW, et al. In utero antiepileptic drug exposure: Fetal death and malformations. Neurology 2006;67(3):407-12. [CrossRef]

16. Bardy AH. Incidence of seizures during pregnancy, labor and puerperium in epileptic women: A prospective study. Acta 
Neurol Scand 1987;75(5):356-60. [CrossRef]

17. Schmidt D, Canger R, Avanzini G, Battino D, Cusi C, Beck-Mannagetta $G$, et al. Change of seizure frequency in pregnant epileptic women. J Neurol Neurosurg Psychiatry 1983;46(8):751-5.

18. Tomson T, Lindbom U, Ekqvist B, Sundqvist A. Epilepsy and pregnancy: A prospective study of seizure control in relation to free and total plasma concentrations of carbamazepine and phenytoin. Epilepsia 1994;35(1):122-30. [CrossRef]

19. Vajda FJ, Hitchcock A, Graham J, O'Brien T, Lander C, Eadie M, et al. Seizure control in antiepileptic drug-treated pregnancy. Epilepsia 2008;49(1):172-6. [CrossRef]

20. Kutlu G, Gömceli YB, Sönmez T, Sanıvar F, İnan LE. Epileptik kadinlarin gebelik sirasinda takip ve tedavisi. Epilepsi 2007;13(2-3):83-6.

21. Bech BH, Kjaersgaard MI, Pedersen HS, Howards PP, Sorensen MJ, Olsen J, et al. Use of antiepileptic drugs during pregnancy and risk os spontaneous abortion and stillbirth: Population based cohort study. BMJ 2014;349:95159. [CrossRef]

22. Othman NH, Ab Rahman AF. Obstetric and birth outcomes in pregnant women with epilepsy: A hospital-based study. Ann Indian Acad Neurol 2013;16(4):534-7. [CrossRef]

23. Veiby G, Daltveit AK, Engelsen BA, Gilhus NE. Pregnancy, delivery, and outcome for the child in maternal epilepsy. Epilepsia 2009;50(9):2130-9. [CrossRef]

24. Viinikainen $\mathrm{K}$, Heinonen S, Eriksson $\mathrm{K}$, Kälviäinen R. Community-based, prospective, controlled study of obstetric and neonatal outcome of 179 pregnancies in women with epilepsy. Epilepsia 2006;47(1):186-92. [CrossRef]
25. Sveberg L, Svalheim S, Taubøll E. The impact of seizures on pregnancy and delivery. Seizure 2015;28:35-8. [CrossRef]

26. Battino D, Tomson T, Bonizzoni E, Craig J, Lindhout D, Sabers $A$, et al. Seizure control and treatment changes in pregnancy: Observations from the EURAP epilepsy pregnancy registry. Epilepsia 2013;54(9):1621-7. [CrossRef]

27. Crawford P. Epilepsy and pregnancy. Seizure 2002;11(A):212-9.

28. Crawford P. Best practice guidelines for the management of women with epilepsy. Epilepsia 2005;46(9):117-24. [CrossRef]

29. Chong DJ, Lerman AM. Practice update: Review of anticonvulsant therapy. Curr Neurol Neurosci Rep 2016;16(4):39.

30. Mawhinney E, Craig J, Morrow J, Russell A, Smithson WH, Parsons $L$, et al. Levetiracetam in pregnancy: Results from the UK and Ireland epilepsy and pregnancy registers. Neurology 2013;80(4):400-5. [CrossRef]

31. Ataklı D. Kadın ve epilepsi. Türk Klin J Neurol Spec Top 2008;1:49-55.

32. Hvas CL, Henriksen TB, Ostergaard JR, Dam M. Epilepsy and pregnancy: Effect of antiepileptic drugs and lifestyle on birthweight. BJOG 2000;107(7):896-902. [CrossRef]

33. Soydinç HE, Turgut A, Sak ME, Özler A, Evsen MS, Başaranoğlu $S$ ve ark. Gebelik ve epilepsi: 46 olgunun retrospektif analizi ve perinatal sonuçların sağlıklı gebelerle karşılaştırılması. Perinatol Derg 2013;21(1):12-6. [CrossRef]

34. Rauchenzauner $M$, Ehrensberger $M$, Prieschl $M$, Kapelari $K$, Bergmann $M$, Walser $G$, et al. Generalized tonic-clonic seizures and antiepileptic drugs during pregnancy-a matter of importance for the baby? J Neurol 2013;260(2):484-8. [CrossRef] 